*alls View/Frint Document Cover Sheet tose

This document was retrieved from the Boeing ISEARCH System.

Accession \#: D196069881

Document \#: SD-WM-TP-350

Title/Desc:

TANK 241B101 TANK CHARACTERIZATION PLAN 


\section{confilate}

\section{ENGINEERING CHANGE NOTICE

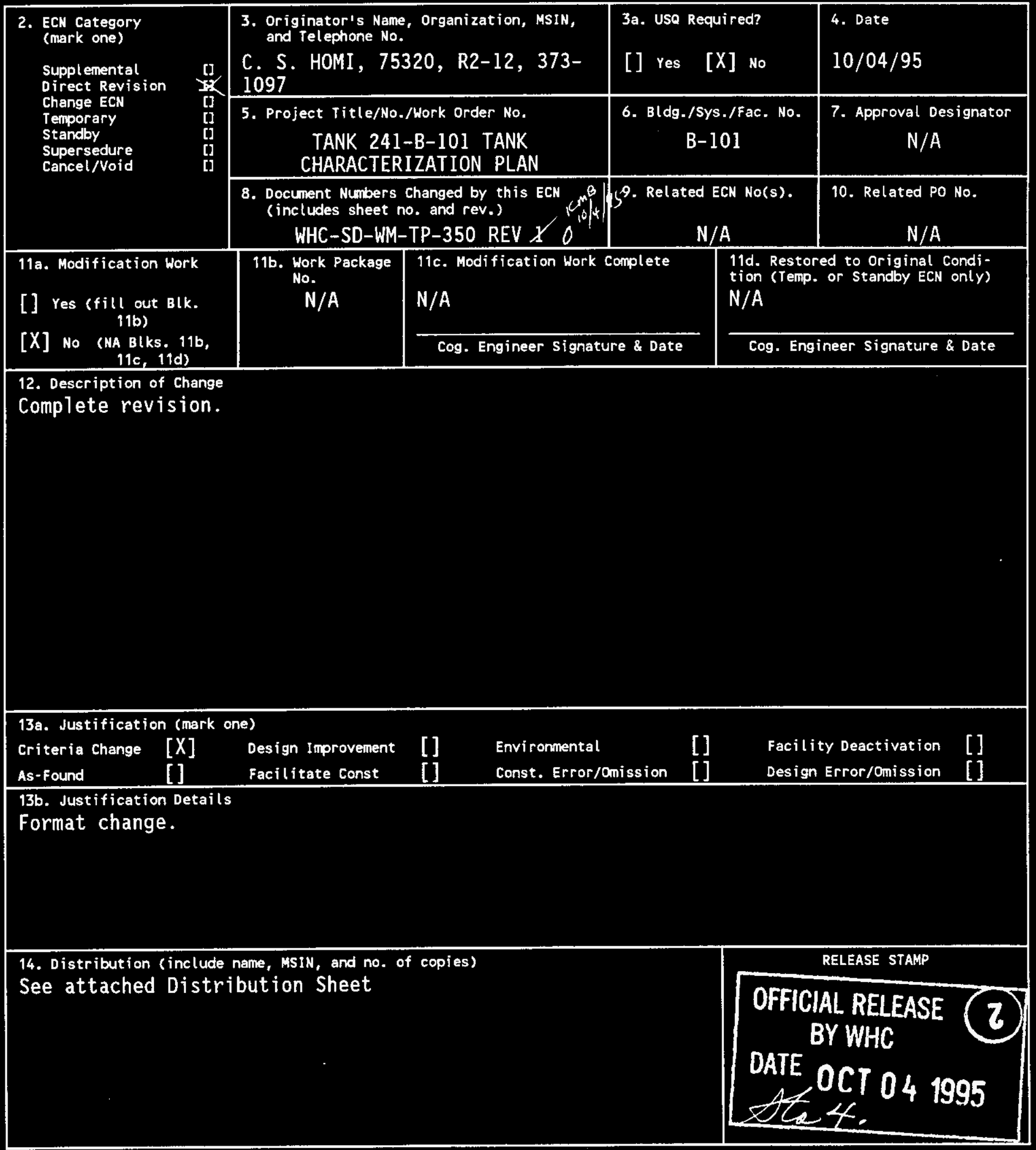




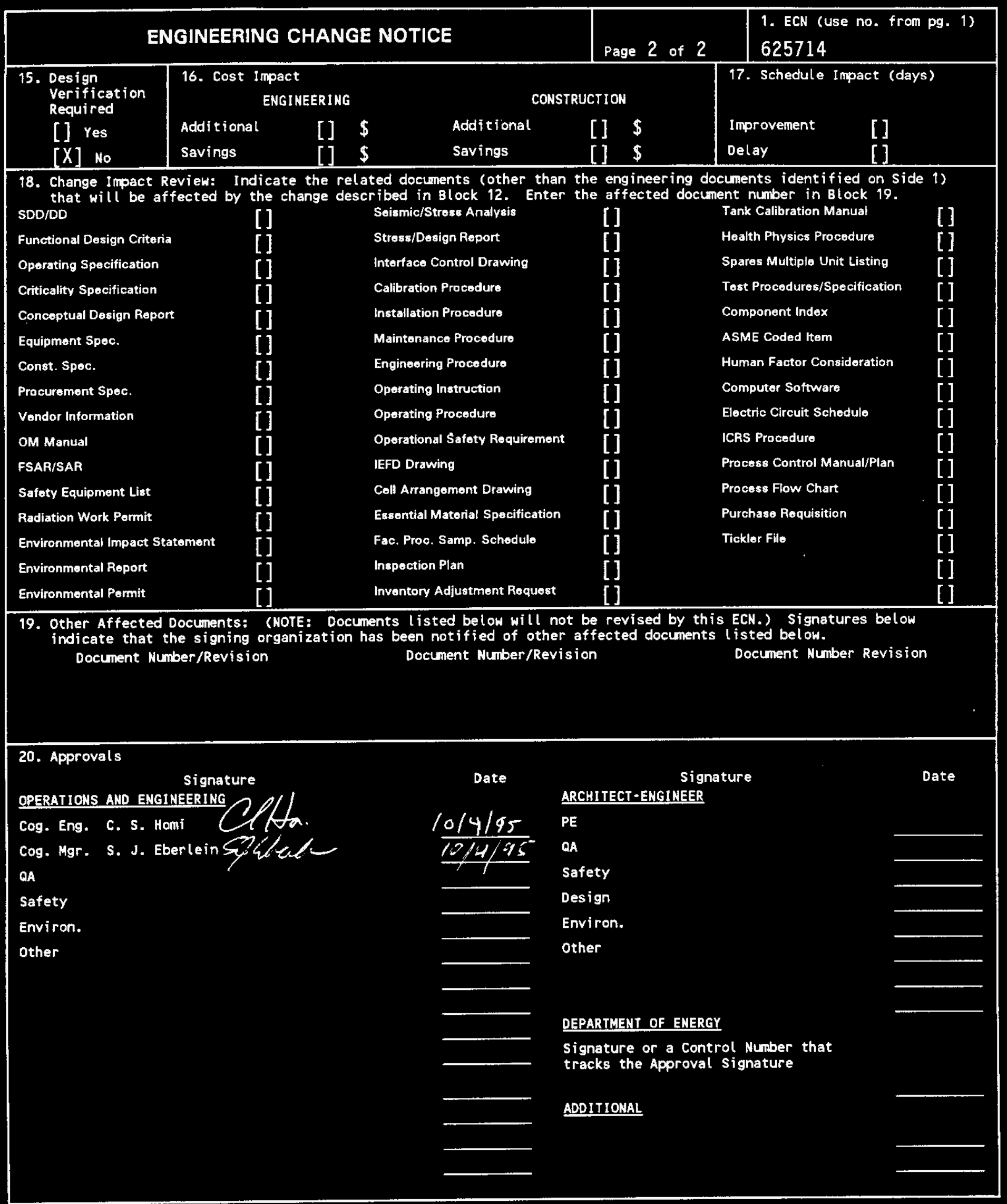




\section{RELEASE AUTHORIZATION}

Document Number: WHC-SD-WM-TP-350, REV 1

Document Title: $\quad$ Tank 241-B-101 Tank Characterization P1an

Release Date: $\quad 10 / 4 / 95$

This document was reviewed following the procedures described in WHC-CM-3-4 and is:

APPROVED FOR PUBLIC RELEASE

WHC Information Release Administration Specialist:
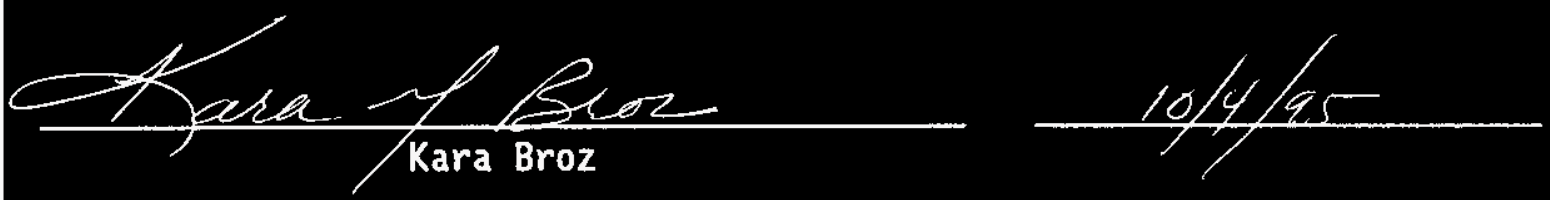

TRADEMARK DISCLAIMER. Reference herein to any specific commercial product, process, or service by trade name, trademark, manufacturer, or otherwise, does not necessarily constitute or imply its endorsement, recommendation, or favoring by the United States Government or any agency thereof or its contractors or subcontractors.

This report has been reproduced from the best available copy. Available in paper copy. Printed in the United States of America. To obtain copies of this report, contact:

Westinghouse Hanford Company - Document Control Services

P.0. Box 1970, Mailstop H6-08, Richland, WA 99352

Telephone: (509) 372-2420; Fax: (509) 376-4989 


\begin{tabular}{|l|l|c|}
\hline 2. Title & $\begin{array}{l}\text { 3. Number } \\
\text { WHC-SD-WM-TP-350 }\end{array}$ & 4. Rev No. \\
TANK 241-B-101 TANK CHARACTERIZATION PLAN & 6. Author \\
\hline $\begin{array}{l}\text { 5. Key Words } \\
\text { CHARACTERIZATION, GENERAL SAFETY ISSUES, SPECIFIC } \\
\text { SAFETY ISSUES, INFORMATION REQUIREMENTS, PRIORITY }\end{array}$ & signature \\
& organization/charge Code $75320 / N 4 G 6 \mathrm{~A}$ \\
\hline
\end{tabular}

\section{Abstract}

This document is a plan that identifies the information needed to address relevant issues concerning short-term and long-term safe storage and long-term management of Single-She11 Tank (SST) 241-B-101.

8.

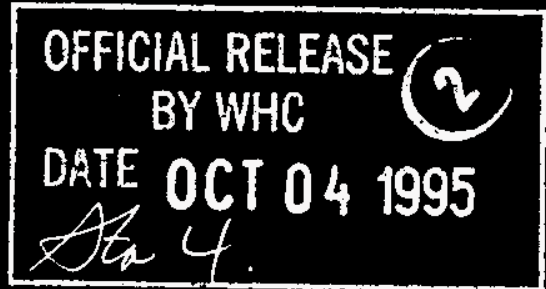


(2) Title

TANK 241-B-101 TANK CHARACTERIZATION PLAN

CHAMEE CONTROL RFCORD

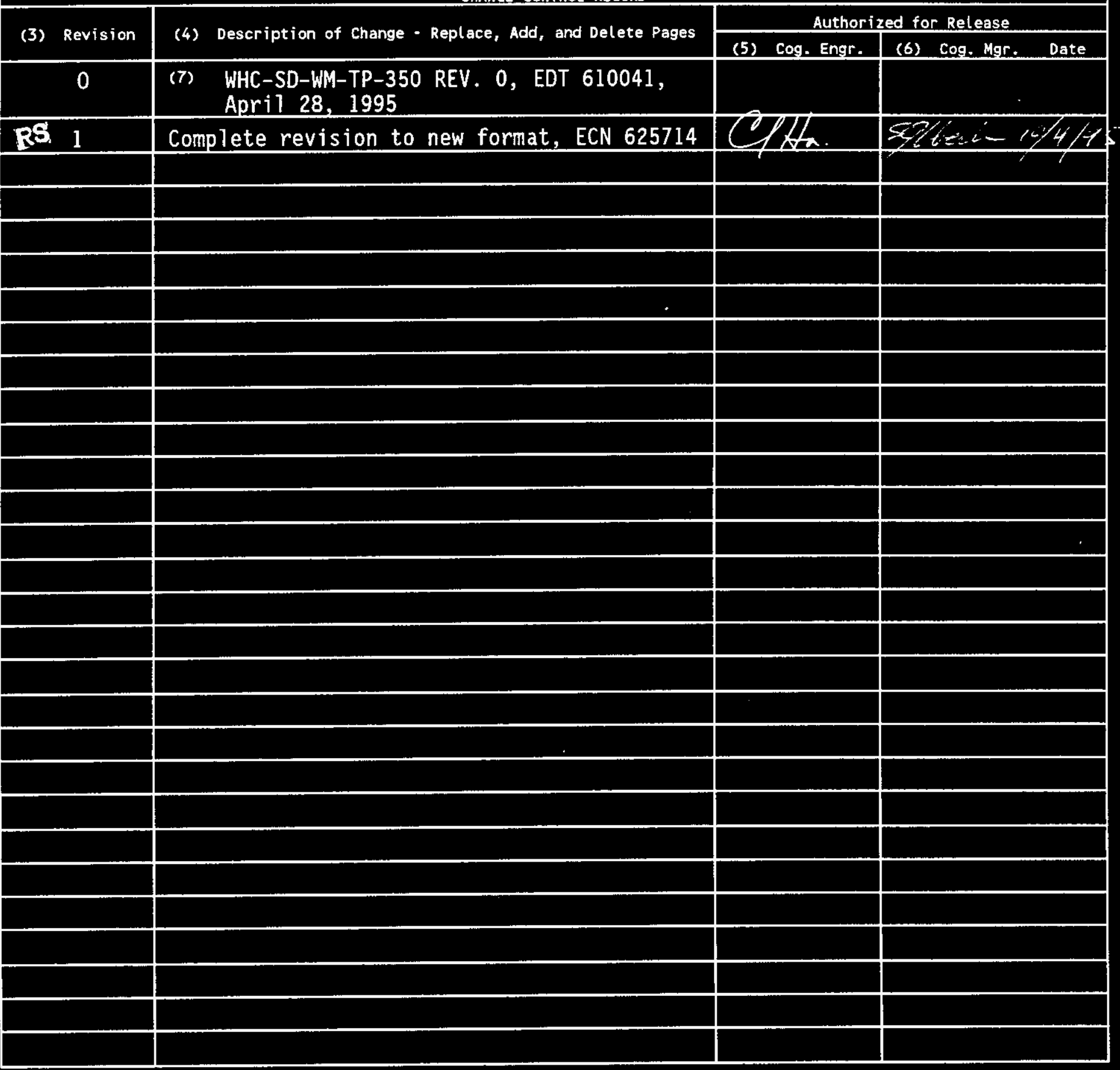




\title{
Tank 241-B-101 Tank Characterization Plan
}

\author{
C. S. Homi \\ Westinghouse Hanford Company
}

\section{Date Published}

October 1995

Prepared for the U.S. Department of Energy Office of Environmental Restoration and Waste Management

\footnotetext{
(27) Westinghouse P.O Box 1970

Hanford Company Richland, Weshington

Menagement and Operations Contractor for the

U.S. Department of Energy under Contract DE.ACO6-87FL 10930
} 


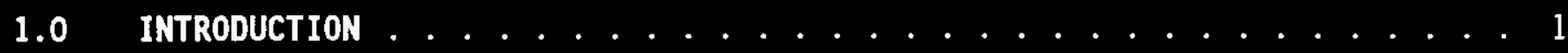

2.0 PROGRAM ELEMENTS REQUIRING INFORMATION FOR 241-B-101 . . . . . . . 2

2.1 GENERAL SAFETY ISSUES . . . . . . . . . . . . . 2

2.2 SPECIFIC SAFETY ISSUES . . . . . . . . . . . . 2

2.2 .1 Ferrocyanide ................ 2

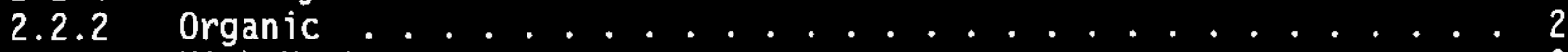

2.2 .3 High Heat .................. 2

2.2 .4 Flammable Gas ................ 2

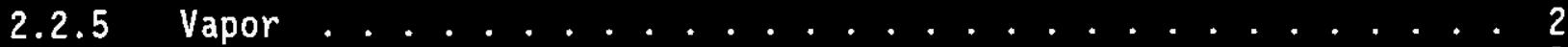

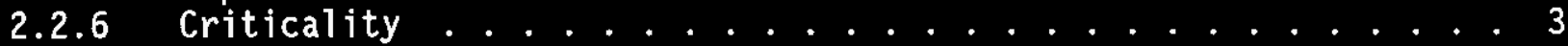

2.2.7 Screening Approach Evaluation ............ 3

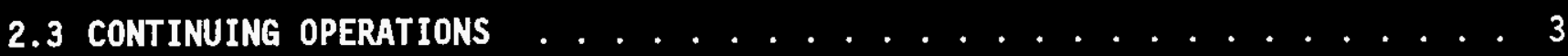

2.2.1 Compatibility/Stabilization ........... 3

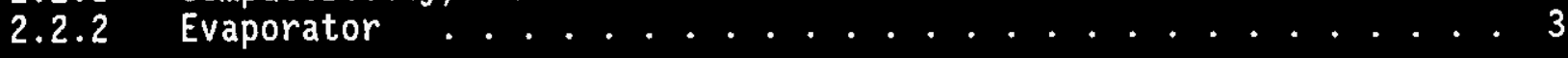

2.4 DOUBLE-SHELL TANK WASTE ANALYSIS PLAN ............ 3

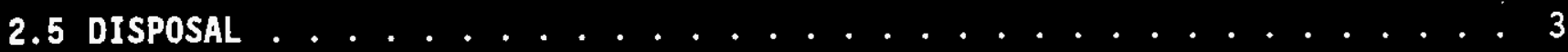

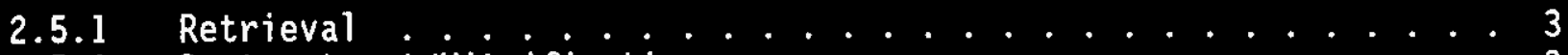

2.5.2 Pretreatment/Vitrification ............ 3

2.6 HISTORICAL MODEL EVALUATION . . . . . . . . . . 3

3.0 HOW INFORMATION WILL BE OBTAINED ............... 4

4.0 PRIORITY OF INFORMATION REQUIREMENTS ............. 4

5.0 WHEN INFORMATION IS NEEDEd ................. 4

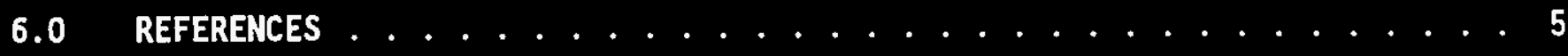

\section{LIST OF TABLES}

Table 4-1: Integrated DQO Requirements ............ 4 
WHC-SD-WM-TP-350, REV 1

LIST OF ABBREVIATIONS

$\begin{array}{ll}\text { B-101 } & \text { Tank 241-B-101 } \\ \text { DQ0 } & \text { Data Quality Objective } \\ \text { HTCE } & \text { Historical Tank Content Est imate } \\ \text { DSSF } & \text { Double Shel1 Slurry Feed } \\ \text { NCPLX } & \text { Non-complexed } \\ \text { SST } & \text { Single-She11 Tank } \\ \text { TCP } & \text { Tank Characterization P1an } \\ \text { TOC } & \text { Total Organic Carbon } \\ \text { USQ } & \text { Unreviewed Safety Question } \\ \text { WHC } & \text { Westinghouse Hanford Company }\end{array}$


WHC-SD-WH-TP-350, REV 1

\subsection{INTRODUCTION}

This Tank Characterization Plan (TCP) identifies the information needed to address relevant issues concerning short-term and long-term safe storage and long-term management of Single-Shell Tank 241-B-101 (B-101). It should be understood that the various needs and issues surrounding tank B-101 are evolving as new information about the tank is uncovered. As a result of this progression, this Tank Characterization Plan addresses only the issues that, to this date, have been identified. It is expected that deviations from this plan may occur as additional issues or needs arise which impact the management of SST B-101. As necessary, this Tank Characterization Plan will be revised to reflect those changes or deviations.

Tank B-101 was constructed between 1943 and 1944 and was put into service in May 1945. Initially tank B-101 received metal waste from the second quarter of 1945 until October 1945. The tank received and transferred waste via cascade 1 ines from 1945 until 1963. During the first quarter of 1953, B-101 processed feed for U Plant. In late December of 1953, the sluicing of metal waste from B-101 was completed. From the fourth quarter of 1953 until the second quarter of 1963, the tank contained evaporator bottoms waste. During the third quarter of 1957, in-farm scavenged feed was sent to the 244-CR Vault. From the second quarter of 1960 until the first quarter of 1970, B-101 received wastewater. Also, it was found that during the second quarter of 1960 wastewater leaked into the pipe encasement which drained to B-101. During the fourth quarter of 1963 the tank received coating waste. B-101 received B Plant high level waste from the second quarter of 1969 until the second quarter of 1970. From the third quarter of 1970 until the first quarter of 1973, the tank received B P1ant low leve1 waste. Presently, the tank waste is classified as non-complexed. This tank currently contains waste with a total waste volume of $427.8 \mathrm{~kL}$ (113 kgal), which is equivalent to 92.8 centimeters ( 36.5 inches) of waste as measured from the baseline of the tank. The waste is comprised of $284 \mathrm{~kL}$ (75 kgal) of saltcake; $38 \mathrm{~kL}(10 \mathrm{kgal})$ of unknown waste and $106 \mathrm{~kL}$ (28 kgal) of sludge with no supernatant and pumpable liquid remaining (Brevick 1994a).

The tank is an assumed leaker (with a leak of approximately $30 \mathrm{~kL}$ [8 kgal] in 1974) and was removed from service in 1974. Tank B-101 is passively ventilated and interim stabilized in March 1981 with intrusion prevention completed. The last photo was taken on May 19, 1983. The 1983 photographic montage cannot be located but, a 1975 montage indicates a solid rough black surface with no visible liquid (Brevick 1994b). The level was adjusted and the supernatant was pumped after this montage was taken; therefore, this montage description does not represent current tank contents. The last solids volume update was obtained on April 28, 1982 (Hanlon 1995).

An analys is was conducted on a B-101 sludge sample in February 1976. The sample was found to have a consistency of soft mud and was dark brown. Particle size distribution, of sample solids, showed that the majority $(90 \mathrm{wt} \%)$ of the soljids was between $5 \mu \mathrm{m}$ and $50 \mu \mathrm{m}$. A heat generation rate based on ${ }^{89} \mathrm{Sr},{ }^{90} \mathrm{Sr}$ and ${ }^{137} \mathrm{Cs}$ was calculated to be 0.0201 watts/liter of sludge.

This tank is not on any Watch 1 ist. Near-term sampling and analysis activities are focused on either verification of the non-watchlist tank status, identification of any new safety issues or changing the non-Watch List status. Should any safety issues be identified additional analysis will occur consistent with the identified issue. 
In addition to the resolution of the safety issues, it is intended that all tank waste will be subject to pretreatment and retrieval to prepare for final storage or disposal. Presently, these long-range plans have yet to be fully identified and are, therefore, not included in this document.

\subsection{PROGRAM ELEHENTS REQUIRING INFORMATION FOR TANK 241-B-101}

This section identifies the various program elements, and identifies which of these programs require characterization data from tank B-101.

\subsection{GENERAL SAFETY ISSUES}

The Tank Safety Screening Data Quality Objective (Redus 1995) describes the sampling and analytical requirements that are used to screen waste tanks for unidentified safety issues. The primary analytical requirements for the safety screening of a tank are energetics, total alpha activity, moisture content, and flammable gas concentration.

\subsection{SPECIFIC SAFETY ISSUES}

\subsubsection{Ferrocyanide}

This tank is not on the Ferrocyanide Watch List and; therefore, no information needs are currently identified for this program element.

\subsubsection{Organic}

Tank B-101 is not on the Organics Watch List and; therefore, no information needs are currently identified for this program element.

\subsubsection{High Heat}

This tank is not on the High Heat Watch List and; therefore, no information needs are currently identified for this program element.

\subsubsection{Flanmable Gas}

This tank is not on the Flammable Gas Watch List and; therefore, no information needs are currently identified for this program element.

\subsubsection{Vapor}

The tanks currently scheduled to be vapor sampled may be classified into four categories: (1) those tanks which are to be rotary mode core sampled (as a consequence of the rotary sampling system); (2) tanks on the Organic or Ferrocyanide Watch Lists; (3) tanks in C farm; and (4) tank BX-104, due to vapor exposure. Since tank B-101 is NOT categorized in one of the above four groups, vapor sampling is not required for this tank. 


\subsubsection{Criticality}

No information separate from that for the general safety issue of tank B-101 are currently identified for this program element. However, if the general safety screening of tank B-101 identifies a potential criticality concern, analyses for fissile materials and neutron absorbers and poisons will be performed as identified in the safety screening data quality objective.

\subsubsection{Screening Approach Evaluation}

The safety screening approach is currently under review. Information is required from key tanks to determine if a revised approach to screening may be adopted, as proposed in Meacham, 1995.

\subsection{CONTINUING OPERATIONS}

\subsubsection{Compatibility/Stabilization}

No information needs are currently identified for this program element.

\subsubsection{Evaporator}

No information needs are currently identified for this program element.

\subsection{DOUBLE-SHELL TANK WASTE ANALYSIS PLAN}

No information needs are currently identified for this program element, al though work to identify these needs is in progress and expected to be completed in fiscal year 1995.

\subsection{DISPOSAL}

\subsubsection{Retrieval}

Current retrieval needs (Bloom 1995) do not call for test samples to be taken from tank B-101.

\subsubsection{Pretreatment/Vitrification}

Tank B-101 has not been identified as an alternate bounding tank for pretreatment/disposal process development (Kupfer 1995).

\subsection{HISTORICAL MODEL EVALUATION}

Bounding tanks and data requirements for historical model evaluations are found in DQO Historical Model Evaluation Data Requirements (Simpson 1995). Tank B-101 has been identified as an alternate bounding tank for any waste type, but will not be evaluated for this DQO unless directed by the program. 


\subsection{HOW INFORMATION WILL BE OBTAINED}

The safety screening DQO requires that a vertical profile of the tank waste be obtained from at least two widely spaced risers. This vertical profile may be obtained using core, auger (for shallow tanks), or grab samples. Only a push mode sampling event is scheduled and required. No other sampling is scheduled through fiscal year 1997 (Stanton 1995). The push mode sampling type has been chosen over other sampling modes due to both the depth of the tank (making auger sampling inadequate) and the fact that the surface of tank B-101 is comprised of supernatant and sludge.

The best current estimate of the water content in tank B-101 solids, as determined from the process records, is $54.0 \%$; based on the HTCE (Brevick 1994a). Estimated (Toth et al 1995) water content in tank B-101 sludge is $34.5 \%$ (generated from a model based on sample data from similar tanks). If the variance of water in tanks already sampled and a statistical power curve is used then a minimum of three cores are needed to demonstrate a water content above $17 \%$ at $95 \%$ confidence. The TOC contained with in the sludge is estimated (Toth et al 1995) to be $0.1 \%$ (wet basis), which is significantly lower than the level of concern. Two core samples will be requested for this tank. Should the measured mean be lower than anticipated or the measured variance higher, additional samples may be required.

Present information indicate that six risers could be available for sampling in tank B-101. Two risers were used during the June 1995 Push Mode sampling event.

\subsection{PRIORITY OF INFORMATION REQUIREMENTS}

Vapor sampling is not required for this tank. Push mode sampling was completed in June 1995 (Stanton 1995).

Table 4-1: Integrated DQO Requirements

\begin{tabular}{|l|l|l|l|}
\hline $\begin{array}{c}\text { Sampling } \\
\text { Event }\end{array}$ & Appl icable DQO & Sampling Requirements & Analytical Requirements \\
\hline $\begin{array}{l}\text { Push Mode } \\
\text { Sampl ing }\end{array}$ & -Safety Screening DQO & $\begin{array}{l}\text { Core samples from 2 } \\
\text { risers separated } \\
\text { radially to the maximum } \\
\text { extent possible } \\
\text { (complete) }\end{array}$ & $\begin{array}{l}\text { Energetics, Moisture, } \\
\text { Total Alpha, Total } \\
\text { Organic Carbon, SpG }\end{array}$ \\
\hline
\end{tabular}

\subsection{WHEN INFORMATION IS NEEDED}

Data are required for Tank B-101 during FY 1996 for safety screening and to prepare a Tank Characterization Report.

\subsection{REFERENCES}


Babad, H, K. S. Redus, and J. W. Hunt, 1995a, Tank Safety Screening Data Quality Objective, WHC-SD-WM-SP-004, Rev 1, Westinghouse Hanford Company, Rich1and, Washington.

Babad, H., S. M. Blacker, and K. S. Redus, 1995b, Data Quality Objective to Support Resolution of the Organic Fuel Rich Tank Safety Issue, WHC-SD-WM-DQ0-006, Rev. 1, Westinghouse Hanford Company, Richland, Washington.

Bloom, G. R., and Q. H. Nguyen, 1995, Characterization Data Needs for Development, Design, and Operation of Retrieval Equipment Developed Through the Data Quality Objective Process, WHC-SD-WM-DQ0-008, Rev. 0, Westinghouse Hanford Company, Richl and, Washington.

Brevick, C. H., 1994a, Historical Tank Content Estimate for the Northeast Quadrant of the Hanford 200 East Areas, WHC-SD-WM-ER-349, Rev. OA, ICF Kaiser Hanford Company, Richland, Washington.

Brevick, C. H., 1994b, Supporting Document for the Historical Tank Content Estimate for BX Tank Farm, WHC-SD-WM-ER-311, Rev. 0, ICF Kaiser Hanford Company, Rich1and, Washington.

Brown, T. M., S. J. Eberlein, D. A. Dodd, T. J. Kunthara, B. C. Simpson, and N. W. Kirch, Tank Waste Characterization Plan and Basis, 1995, WHC-SD-WM-TA-164, Rev 0, Westinghouse Hanford Company, Richland, Washington.

Hanlon, B.M., 1995, Waste Tank Summary for Month Ending May, 1995, WHC-EP-0182-82, Westinghouse Hanford Company, Richland, Washington.

Homi, C. S., and S. J. Eberlein, 1995, Fiscal Year 1996 Tank Waste Remediation System Tank Waste Analysis Plan, WHC-SD-WM-PLN-101, Rev 0, Westinghouse Hanford Company, Richland, Washington

Kupfer, M. J., W. W. Schultz, and J. T. Slankas, 1995, Strategy for Sampling Hanford Site Tank Wastes for Development of Disposal Technology, WHC-SD-WM-TA-154, Rev. 1, Westinghouse Hanford Company, Richland, Washington.

Meacham, J. E., R. J. Cash, B. A. Pulsipher, and G. Chen, 1995, Data Requirements for the Ferrocyanide Safety Issue Developed through the Data Quality Objectives Process, WHC-SD-WM-DQO-007, Rev. 1, Westinghouse Hanford Company, Richland, Washington.

Osborne, J.W., J.L. Huckaby, E.R. Hewitt, C.M. Anderson, D.D. Mahlum, B.A. Pulsipher, and J.Y. Young, 1995, Data Quality Objectives for Generic In-Tank Health and Safety Vapor Issue Resolution, WHC-SD-WM-DQO-002, Rev. 1, Westinghouse Hanford Company, Richland, Washington.

Price, D. N., 1994, Rotary Core Vapor Sampling Data Quality Objective, WHC-SD-WM-SP-003, Rev. 0, Westinghouse Hanford Company, Richland, Washington.

Simpson, B. C., and D. J. McCain, 1995, Historical Model Evaluation Data Requirements, WHC-SD-WM-DQO-018, Rev. 0, West inghouse Hanford Company, Richland, Washington.

Stanton, G. A., 1995, Baseline Sampling Schedule, Revision 4.4, (internal memo 74320-95-04, to distribution, March 24), Westinghouse Hanford Company, Rich1and, 
Washington.

Toth, J. J., P. G. Heasler, M. E. Lerchen, J. G. Hill, and P. D. Whitney, 1995, Analysis of Organic Carbon and Moisture in Hanford Single-She 71 Tank Waste, PNL10360, Pacific Northwest Laboratory, Richland, Washington. 